\author{
ポーセレン ラミネートベニアの成功率 \\ 中川孝 男* 保母 須弥也*
}

\title{
Success Rate of Porcelain Laminate Veneers
}

\section{Takao Nakagawa* Sumiya Hobo*}

Success rate of porcelain laminate veneers in the International Dental Academy Clinics, Tokyo, was $98.0 \%$ among 711 teeth of 251 patients treated during the period of 1985 1992.

The total number of failured teeth was 14, among which veneers on 6 teeth fell down, dental pulps in 5 were gangrenous, and veneers on 3 were broken.

\section{緒言}

前歯の唇面にポーセレンのシェルを接着して審 美性を回復するポーセレンラミネートベニア法 は, 1983年に Simonsen と Calamia1) がポーセレ ンの表面をフッ化水素酸でェッチングして顕微鏡 的な微小窩を作り，コンポジットレジンのタグを 陷入させることによって強力な機械的接着力を付 与する方法を発見して以来, 急速に普及した。し かしその成功率については定量的なデータがまだ 発表されていない. 本報告は国際デンタルアカデ ミーにおいて過去 7 年間に製作し臨床適用した, ポーセレン ラミネートベニア（以下ラミネート という）の成功率の調査結果である.

\section{方法}

国際デンタルアカデミーでは1984年にラミネー トの臨床適用を開始したが，当初は材料の質が不 十分で，また技術的にも不明確な部分が多く，技 術・材料の両面で安定したレベルが確立したのは 1985 年以降である ${ }^{2 \sim 5)}$. したがって本調査は 1985

* 国際デンタルアカデミ-
〜1992年の 7 年間に当アカデミーにおいて製作し たラミネートを, 実際臨休に適用した711歯につい て央施した。ちなみに患者数は251 名であった。

\section{結果}

711 本のラミネート適用歯のらち失敗例は 14畨 であった，失敗の内訳は，脱落 6 歯，歯髄死 5 歯， 破折 3 歯となっている．したがって成功率は98. 0 \%である. 患者数でいらと, 脱落 4 , 歯髄死 4 , 破折 3 となり, 計 11 症例 (4.4\%) に失敗があっ たことになる。

表 ラミネートの成功率

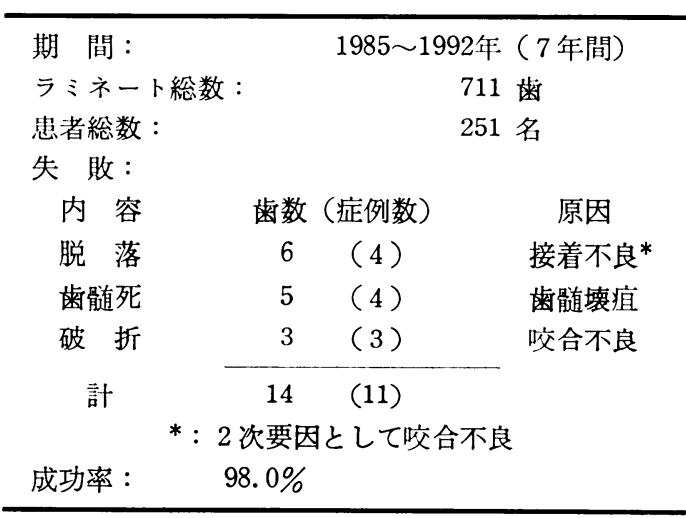


上記失敗例の 14 蒾における発生時期を術後の経 過期間でみると， 1 週間以内が 2 歯（脱落, 破折 各 1)，他はそれ以上であった。 また原因分析結 果を項目別にみると, 接着不良 6 歯, 幽䯣壊疽 5 雪, 咬合不良 3 歯であった。因果関係では，接着 不良之脱落, 歯髄壊瘨と歯髄死, 咬合不良之破折 がそれぞれ対応していた。

表に今回の調査結果をまとめて示す.

\section{考察}

14歯の失敗例の因果関係と予防措置について考 察した. 以下内容別に述べる.

ラミネートの脱落（6歯）の主たる発生原因は 接着不良と判定した。脱落を招く剝離はエナメル 質とレジンの間に生じ，ラミネートとレジンが剝 離することはない.エナメル質とレジンが剝離す る具体的理由は汪とんどのケースに拈いて不十分 な防湿処置に帰せられる。接着作業にあたっては 接着する歯面をよく乾燥した後エッチング液を少 量塗布し, 水洗後再びよく乾燥してから裏面にコ ンポジットレジンを叙布したラミネートを压接し て表面から十分可視光線を照射するが，乾燥のあ と唾液や歯肉溝からの滲出液により歯面が污染さ れるのを防ぐため，歯肉圧排とラバーダムによる 防湿が必要である. 例外的に, フィニシングライ ンがセメント質まで延長されていたために，十分 な接着力が得られず脱落したとみられるケースが 1 歯あった。 なお，上記 6 歯のうち 4 歯が下顎切 歯であったことから，(これらの患歯は切端咬合 ではなかったが）これは上顎切歯の唇面には咬合 力が作用しないのに対し，下顎切歯の唇面には咬 合力が加わるためと考光, 脱落を加速する 2 次要 因としては咬合力の影響を無視することができな いと判断した。

壊疽による歯梿死（4粦）は，歯牙の切削量が 多く象牙質が露出したと思われる症例に発生した が，形成の際の削合量が同程度でも発生したり， しなかったりするので，患者によって歯髄反応の 感度に若干相違があるようである．象牙質の露出 を防ぐために，形成の際のエナメル質の削合量を $0.5 \mathrm{~mm}$ 以内と定めた。なお，米髄死を招いた患
歯は抜髄して根管治療を行ったが，そのうち 1 例 では象牙質面に充血による斑点が表われ根管治潦 後もラミネートを透して視認されたので再製処置 を丰施した。

破折（3 料）の発生原因はすべて咬合不良と判 定した。切端咬合などの咬合不良により偏心運動 中にラミネートに過重な負担が加わると, ラミネ 一トが破折したり脱落を加速したりすると考学ら れる. Albers ら ${ }^{6)}$ はラミネートを失敗に導く最多 発原因は咬合不良であり，ラミネートにストレス （歪応力）が蓄積されるとマイクロクラックが発 生し, 機能運動中にラミネートが壊れると述べて いる. 今回の調查の分析過程に掞いて, 破折籶の 中に矮小歯を正常な形態に大きくした症例（図 1 4)があったので，さらに詳細に調べた結果，天 然雨の外形よりもラミネートを $1 \sim 2 \mathrm{~mm}$ 以上延 長すると天然幽によるポーセレンの支持力が不十 分となり，偏心運動中に直接ラミネートに加わる 咬合力に耐えられなくなって，ラミネートの破折 を生じやすいことが分かった。

上記のように破折の発生原因は咬合不良である が, 前述したように脱落の発生にも咬合力が加速 要因として関与する. 防湿や象牙質の露出防止は 上述の対策で十分と考兄られるが，咬合力の影響 は症例により多岐に作用するので, 咬合力の為害 作用には細心の注意を払わなければならない。一 般にラミネートの術式は審美歯科の分野に限られ ると考えられがちであるが，以上述べた理由によ り破折や脱落の失敗を根絶するためには，咬合の 診査を十分に行う必要があることはあきらかであ ると考える. 特に, 側方運動誘導の際大きな荷重 がかかる犬雨のアンテリア・ガイダンス部分まで ラミネートを延長することは，早晚ラミネートの 破折または脱落を招く颃それが大きいといえよ 5 .

図 5〜 7 にラミネート法による成功例の 1 つを 示す.

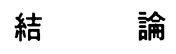

1. 国際デンタルアカデミーにおけるポーセレ ンラミネートベニア（711歯）の臨床成功率は, 
98.0\%であった.

2. 失敗例の発生順位は, 内容別にみると脱落, 歯髄死，破折の順であり，原因別にみると接着不 良, 歯髄壊疽, 咬合不良の順であった。

3. ラミネートに直接咬合力が加わるような咬 合はできる限り避ける必要があり, 特に犬歯のア ンテリア・ガイダンス部分までラミネートを延長 することは禁忌とすべきである.

4. ラミネートを天然歯の外形より $1 \sim 2 \mathrm{~mm}$ 以上延長してはならない.

5. 接着操作中に 乾燥する際に，睡液などによ り歯面が污染されると接着力が低下するので，歯 肉圧排とラバーダムによる防湿が必要である.

6. 形成の際のエナメル質の削合量は $0.5 \mathrm{~mm}$ 以内に留めるべきである.

\section{考文献}

1) Simonsen, R.J., Calamia, J.R.: Tensile bond strength of etched porcelain. L.A.D.R. Abstracts, 1154: 297, 1983.

2) Horn, H.R.: Porcelain laminate veneers bonded to etched enamel. P. Clin. N. Am., 27: 4, 1983.

3) Calamia, J.R.: Etched porcelain veneers: The current state of the art. Quintessence Int: 1, 1985.

4) Barnes, D.M., Strassler, H.E.: Veneers: A comparison of three techniques. Esthetic Dentistry Update 1: 5, 1990.

5）保母須弥也：ポーセレンラミネートベニアと 3 次元シェード再生テクニック :スペシャル シン ポジウム II : An esthetic dentistry, (東京), 1990.

6) Albers, H.F. (ed.): Porcelain veneer fabrication. Adept Report 1: 3, 1990.

別刷請求先：中川孝男

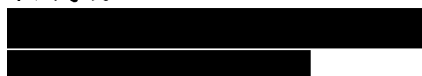

国際デンタルアカデミー 


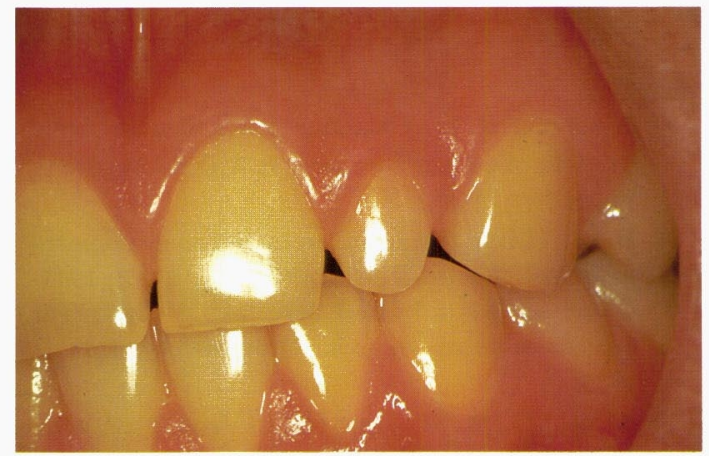

図 1 術前：患者は $\mid 2$ の矮小歯を主訴として来院, ラミネートで修復することとした。

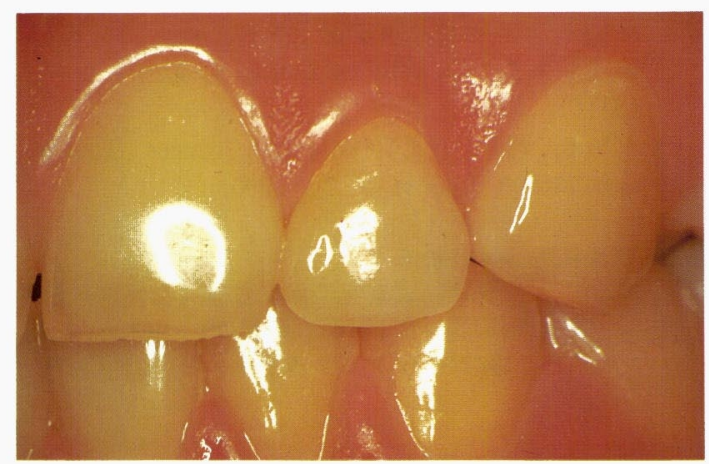

図 3 術後の唇面観 : 矮小歯の隣接面および切縁は 審美的な形態に回復されている.

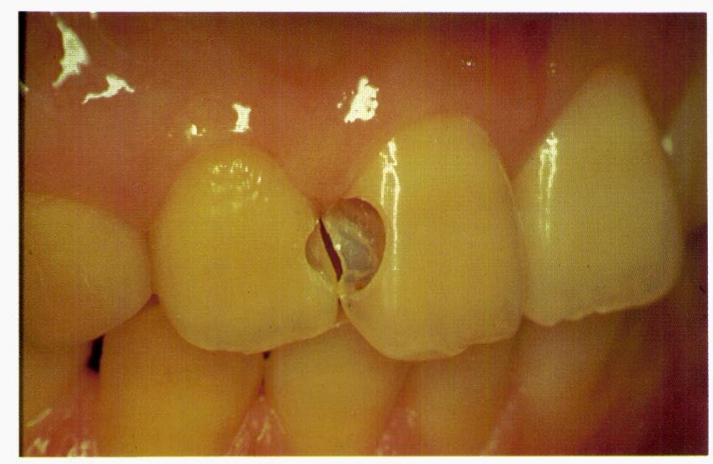

図 5 術前： $2 \underline{1} \mid$ のら蝕を主訴として来院， $\underline{2}$ | は コンポジット・レジンで修復し， $1 \mid$ はラミ ネート修復することとした。

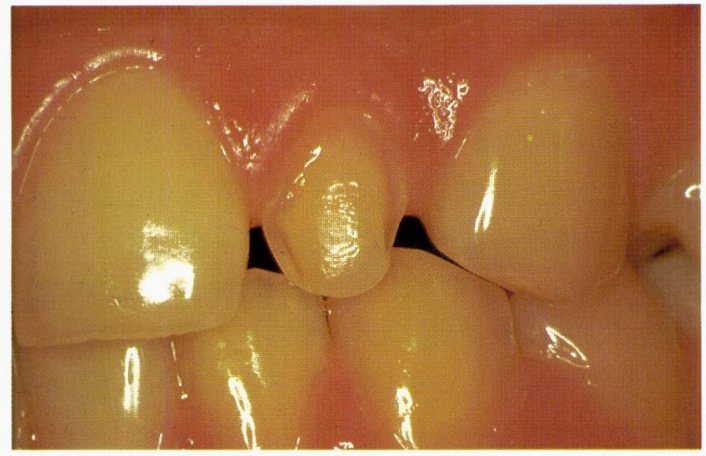

図 2 プレパレーション後

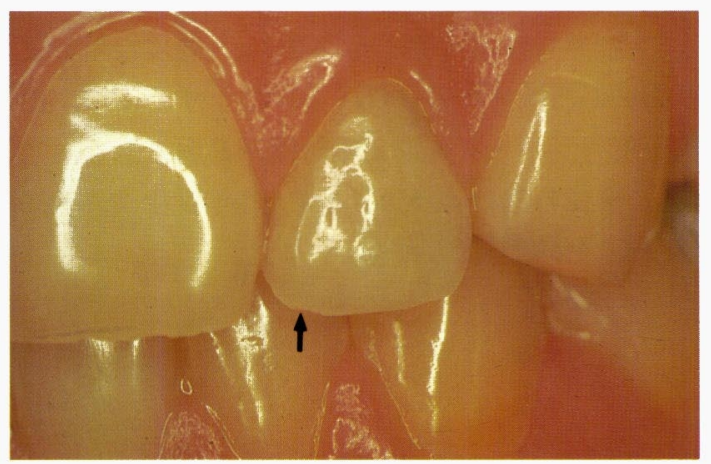

図 4 修復から 6 カ月後, 近心の切縁部がチップし ていた (矢印).このケースのように歯牙の 形態を変更した場合には, 偏心運動時の初期 接触に注意する必要がある。

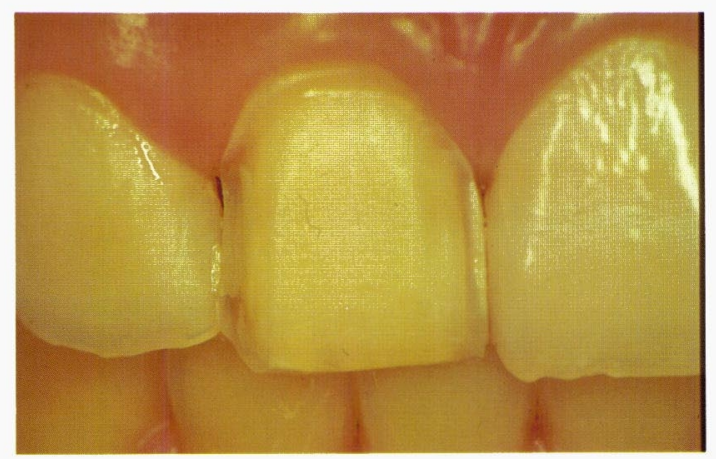

図 6 プレパレーション後

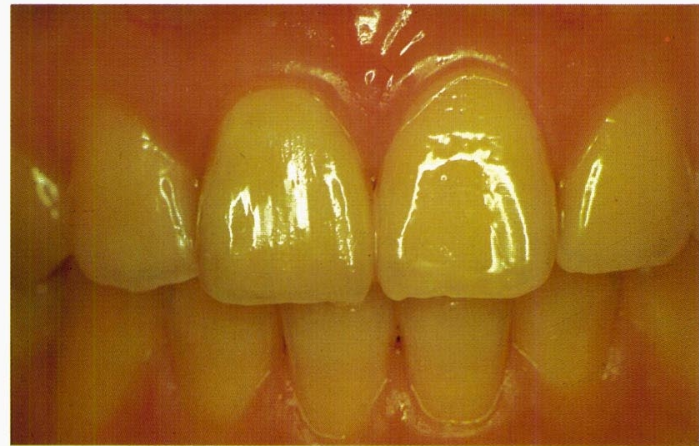

図 7 修復後唇面観 